\title{
Measuring the relative efficiency of insurance industry: Evidence from Tehran Stock Exchange
}

\author{
Maryam Mousavi ${ }^{\mathrm{a}}$ and Seyedeh Mahboubeh Jafari ${ }^{\mathbf{b}^{*}}$
}

${ }^{a}$ Master's Student, Department of Management and Accounting, Islamic Azad University, Tehran South Branch, Tehran, Iran ${ }^{b}$ Faculty member, Department of Management and Accounting, Islamic Azad University, Tehran South Branch, Tehran, Iran

\section{H R O N I C L E}

\begin{tabular}{l}
\hline Article history: \\
Received March 25, 2015 \\
Received in revised format \\
August 162015 \\
Accepted August 292015 \\
Available online \\
August 312015 \\
\hline Keywords: \\
Insurance industry \\
Efficiency \\
Tehran Stock Exchange \\
\hline
\end{tabular}
\begin{abstract}
A B S T R A C T
Measuring the relative efficiency in insurance industry plays essential role for productivity improvement in insurance industry. In this paper, we present an empirical investigation to measure the relative efficiency of some insurance firms listed on Tehran Stock Exchange using data envelopment analysis (DEA) over the period 2011-2013. The proposed study of this paper uses four inputs namely; total assets, price to earnings ratio, beta and sigma and four outputs namely; net earnings, one-year, two-year and three-year returns. The study uses two methods of input and output oriented DEA to measures the relative efficiencies of 9 banks and the results indicate that most insurance firms perform well in terms of efficiency.
\end{abstract}

() 2015 Growing Science Ltd. All rights reserved.

\section{Introduction}

Measuring the relative efficiency in insurance industry plays essential role for productivity improvement in insurance industry (Brockett et al., 1998; Saad, 2006). Charnes et al. (1978) are believed to be the first who introduced the idea of data envelopment analysis (DEA) for measuring the relative efficiency of different firms and there have been tremendous efforts on contributing to the idea of DEA method. Cummins and Weiss (2013) presented a comprehensive analysis for firm performance in the insurance industry using frontier efficiency and productivity techniques. Brockett et al. (2005) compared financial intermediary against production approach to efficiency of marketing distribution systems and organizational structure of insurance companies. Cummins et al. (2003) investigated economies of scope in financial services by implementing DEA bootstrapping analysis of the US insurance industry. Barros et al. (2010), Cummins and Zi (1997), Hardwick et al. (2003), Klumpes (2004) and Kasman and Turgutlu (2007), Sinha et al. (2009), Md Saad et al. (2011) and measured cost efficiency in the Greece, United States, United Kingdom, Turkish, India and Malaysian life insurance industry by applying different kinds of DEA methods. Diboky and Ubl (2007) investigated ownership and efficiency in the German life insurance market using DEA bootstrap method. Shujie et al. (2007)

\footnotetext{
* Corresponding author. Tel: +989124759473

E-mail address: majafari22@gmail.com (S. M. Jafari) 
performed an investigation on technical efficiency of China's insurance industry after the country joined to WTO. Retzlaff-Roberts and Puelz (1996) performed a survey on classification in automobile insurance using a DEA and discriminant analysis hybrid. Chen (1998) determined the comparative efficient firms of insurance industries through the implementation of DEA method. Wei (2009) investigated efficiency of insurance fund utilization in China's insurance companies using a resourcebased two-stage DEA model. Brockett et al. (2004) performed an empirical investigation to evaluate solvency versus efficiency performance and various forms of organization and marketing in US property-liability insurance firms.

\section{The proposed study}

This paper presents an empirical investigation to measure the relative efficiency of some firms listed on Tehran Stock Exchange using data envelopment analysis (DEA) over the period 2011-2013. Charnes et al. (1978) are believed to be the first who introduced the idea of DEA for measuring the relative efficiency of different firms as follows,

$\max \Theta_{o}=\sum u_{r} y_{r o}$

subject to

$$
\begin{array}{lc}
\sum u_{r} y_{r j}-\sum v_{i} x_{i j} \leq 0 & \mathrm{j}=1,2, \ldots, \mathrm{n} \\
\sum v_{i} x_{i o}=1 & \mathrm{i}=1,2, \ldots, \mathrm{m} \\
\mathrm{u}_{\mathrm{r}}, \mathrm{v}_{\mathrm{i}} \geq 0 & \mathrm{r}=1,2, \ldots, \mathrm{s}
\end{array}
$$

Here, $x_{i j}$ and $y_{r j}$ represent inputs and outputs and $\mathrm{u}_{\mathrm{r}}, \mathrm{v}_{\mathrm{i}}$ represent dual variables associated with input/output variables, respectively. The study assumes there are $m$ criteria and $n$ units. The input oriented DEA can be formulated as follows,

$\min \Phi$

subject to

$$
\begin{array}{cc}
\sum \lambda_{j} x_{i j} \leq \Phi x_{\text {io }} & \mathrm{i}=1,2, \ldots, \mathrm{m} \\
\sum \lambda_{j} y_{r j} \geq y_{\text {ro }} & \mathrm{j}=1,2, \ldots, \mathrm{n} \\
\lambda_{\mathrm{j}} \geq 0 & \mathrm{r}=1,2, \ldots, \mathrm{s} \\
\Phi \text { free in sign } &
\end{array}
$$

The first DEA model is established based on a simple criteria, which is constant return to scale. However, Banker et al. (1984) and Banker and Thrall (1992) proposed variable return to scale DEA.

$\max \Theta_{\mathrm{o}}=\sum u_{r} y_{r o}+w$

subject to

$$
\begin{array}{lr}
\sum v_{i} x_{i o}=1 & \mathrm{i}=1,2, \ldots, \mathrm{m} \\
\sum u_{r} y_{r j}-\sum v_{i} x_{i j}+w \leq 0 & \mathrm{j}=1,2, \ldots, \mathrm{n} \\
\mathrm{u}_{\mathrm{r}}, \mathrm{v}_{\mathrm{i}} \geq 0 & \mathrm{r}=1,2, \ldots, \mathrm{s}
\end{array}
$$

w free in sign 
and dual of this problem is written as follows,

$\min \Phi$

subject to

$$
\begin{array}{lr}
\sum \lambda_{j} x_{i j} \leq \Phi x_{\text {io }} & \mathrm{i}=1,2, \ldots, \mathrm{m} \\
\sum \lambda_{j} y_{r j} \geq y_{\text {ro }} & \mathrm{j}=1,2, \ldots, \mathrm{n} \\
\sum \lambda_{\mathrm{j}}=1 & \mathrm{r}=1,2, \ldots, \mathrm{s} \\
\lambda_{\mathrm{j}} \geq 0 & \\
\Phi \text { free in sign } &
\end{array}
$$

where $\lambda_{j}$ represents dual variable.

Finally, there is another type of DEA model, which is output oriented and it is expressed as follows,

$$
\max \Theta_{0}=\sum v_{i} x_{i o}
$$

subject to

$$
\begin{array}{lc}
\sum u_{r} y_{r o}+w=1 & \mathrm{i}=1,2, \ldots, \mathrm{m} \\
\sum u_{r} y_{r j}-\sum v_{i} x_{i j}+w \leq 0 & \mathrm{j}=1,2, \ldots, \mathrm{n} \\
\mathrm{u}_{\mathrm{r}}, \mathrm{v}_{\mathrm{i}} \geq 0 & \mathrm{r}=1,2, \ldots, \mathrm{s} \\
&
\end{array}
$$

\begin{tabular}{|c|c|c|c|c|c|c|c|}
\hline \multirow[b]{2}{*}{ Var. } & & \multicolumn{2}{|c|}{2011} & \multicolumn{2}{|c|}{2012} & \multicolumn{2}{|c|}{2013} \\
\hline & & $\mathrm{Z}$ & Sig. & $\mathrm{Z}$ & Sig. & $\mathrm{Z}$ & Sig. \\
\hline $\mathrm{X}_{1}$ & Total assets & 0.236 & 0.200 & 0.231 & 0.200 & 0.205 & 0.200 \\
\hline $\mathrm{X}_{2}$ & Price/Earnings & 0.027 & 0.200 & 0.205 & 0.200 & 0.165 & 0.200 \\
\hline $\mathrm{X}_{3}$ & Beta & 0.251 & 0.078 & 0.213 & 0.200 & 0.222 & 0.200 \\
\hline $\mathrm{X}_{4}$ & Sigma & 0.278 & 0.200 & 0.217 & 0.200 & 0.201 & 0.188 \\
\hline$Y_{1}$ & Net earnings & 0.234 & 0.127 & 0.198 & 0.200 & 0.202 & 0.200 \\
\hline $\mathrm{Y}_{2}$ & One-year return & 0.202 & 0.200 & 0.205 & 0.200 & 0.212 & 0.200 \\
\hline$Y_{3}$ & Two-year return & 0.264 & 0.083 & 0.263 & 0.200 & 0.220 & 0.200 \\
\hline $\mathrm{Y}_{4}$ & Three-year return & 0.235 & 0.178 & 0.231 & 0.182 & 0.226 & 0.200 \\
\hline
\end{tabular}

There is also another method, which reduces inputs and increases outputs, simultaneously as follows,

$$
\begin{aligned}
& \min z=-\sum s_{i}^{-}-\sum s_{r}^{+} \\
& \text {subject to: } \\
& \sum-\lambda_{\mathrm{j}} x_{i j}+s_{i}^{-}=x_{i o} \\
& \sum-\lambda_{\mathrm{j}} y x_{r j}+s_{r}^{+}=y_{r o} \\
& \sum \lambda_{\mathrm{j}}=1, \lambda_{\mathrm{j}} \geq 0
\end{aligned}
$$

The proposed study of this paper uses four inputs namely; total assets, price to earnings ratio, beta and sigma and four outputs namely; net earnings, one-year, two-year and three-year returns. Table 1 demonstrates the implementation of Kolmogorov-Smirnov test to learn whether the data were normally distributed or not. As we can observe from the results of Table 1, all data are normally distributed.

\section{Table 1}

The summary of Kolmogorov-Smirnov test 


\section{The results}

The proposed model of this paper uses two DEA models of input oriented and output oriented to measure the relative efficiencies of nine insurance firms, proposed by Banker et al. (1984), and Table 2 summarizes the results.

\section{Table 2}

The summary of the implementation of DEA method

\begin{tabular}{lccccccc}
\hline & \multicolumn{3}{c}{ Output oriented } & \multicolumn{3}{c}{ Input oriented } \\
\cline { 2 - 8 } Bank & 2011 & 2012 & 2013 & Bank & 2011 & 2012 & 2013 \\
\hline 1 & 00.1 & 00.1 & 00.1 & 1 & 1.00 & 1.00 & 1.00 \\
2 & 00.1 & 00.1 & 00.1 & 2 & 1.00 & 1.00 & 0.94 \\
3 & 00.1 & 0.95 & 00.1 & 3 & 1.00 & 1.00 & 1.00 \\
4 & 00.1 & 00.1 & 00.1 & 4 & 0.98 & 1.00 & 1.00 \\
5 & 00.1 & 00.1 & 00.1 & 5 & 1.00 & 0.95 & 1.00 \\
6 & 00.1 & 00.1 & 00.1 & 6 & 1.00 & 1.00 & 1.00 \\
7 & 96.0 & 00.1 & 00.1 & 7 & 0.97 & 1.00 & 1.00 \\
8 & 0.93 & 0.97 & 0.91 & 8 & 1.00 & 1.00 & 1.00 \\
9 & 00.1 & 00.1 & 00.1 & 9 & & & \\
\hline
\end{tabular}

As we can observe from the results of Table 2, most insurance firms remained efficient and therefore, we need to perform super efficiency method (Andersen \& Petersen, 1993). Table 3 demonstrates the summary of our results.

\section{Table 3}

The summary of supper efficiency

\begin{tabular}{lcc}
\hline Bank & Efficiency & Anderson \& Peterson \\
\hline 1 & 1 & 1.8073 \\
2 & 1 & 1.8036 \\
3 & 1 & 1.7425 \\
4 & 1 & 1.6359 \\
5 & 1 & 1.6331 \\
6 & 0.993 & \\
7 & 0.983 & \\
8 & 0.98 & \\
9 & 0.97 & \\
\hline
\end{tabular}

\section{Discussion and conclusion}

Measuring the relative efficiency of insurance firms has become a necessity since there is a tight competition among insurance service providers across the world. There is no doubt that DEA method has proven to be one of the most important techniques to learn about the status of an insurance firm. In this paper, we have performed DEA technique to measure the relative efficiencies of some major banks listed on Tehran Stock Exchange. The results of this study has indicated that all firms were relatively efficient compared with each other. We have also measured super efficiency for some insurance firms, which were detected efficient according to BBC technique to have better insight about efficiency of the industry.

\section{Acknowledgement}

The authors would like to thank the annonymous referees for constructive comments on earlier version of this paper. 


\section{References}

Andersen, P., \& Petersen, N. C. (1993). A procedure for ranking efficient units in data envelopment analysis, Management Science, 39, 1261-1264.

Banker, R. D., Charnes, A., \& Cooper, W. W. (1984). Some models for estimating technical and scale inefficiencies in data envelopment analysis.Management science, 30(9), 1078-1092.

Banker, R. D., \& Thrall, R. M. (1992). Estimation of returns to scale using data envelopment analysis. European Journal of Operational Research, 62(1), 74-84.

Barros, C. P., Nektarios, M., \& Assaf, A. (2010). Efficiency in the Greek insurance industry. European Journal of Operational Research, 205(2), 431-436.

Brockett, P. L., Cooper, W. W., Golden, L. L., Rousseau, J. J., \& Wang, Y. (1998). DEA evaluations of the efficiency of organizational forms and distribution systems in the US property and liability insurance industry.International Journal of Systems Science, 29(11), 1235-1247.

Brockett, P. L., Cooper, W. W., Golden, L. L., Rousseau, J. J., \& Wang, Y. (2004). Evaluating solvency versus efficiency performance and different forms of organization and marketing in US property-liability insurance companies.European Journal of Operational Research, 154(2), 492-514.

Brockett, P. L., Cooper, W. W., Golden, L. L., Rousseau, J. J., \& Wang, Y. (2005). Financial intermediary versus production approach to efficiency of marketing distribution systems and organizational structure of insurance companies. Journal of Risk and Insurance, 72(3), 393-412.

Charnes, A., Cooper, W. W., Rhodes, E. (1978). Measuring the efficiency of decision making units. European Journal of the Operational Research, 2, 429-44.

Charnes, A., Cooper, W. W., Lewin, A., Seiford, L. M. (1994). Data envelopment analysis: theory, methodology and applications. Massachusetts: Kluwer Academic Publishers.

Chen, T. Y. (1998). Determining the comparative efficient units of insurance industries through DEA. Journal of Professional Services Marketing, 18(2), 105-118.

Cummins, J. D., \& Zi, H. (1997). Measuring cost efficiency in the US life insurance industry: Econometric and mathematical programming approaches.Financial Institutions Center, The Wharton School Working Paper, University of Pennsylvania.

Cummins, J. D., Weiss, M. A., \& Zi, H. (2003). Economies of scope in financial services: A DEA bootstrapping analysis of the US insurance industry.Unpublished manuscript, The Wharton School, Philadelphia, PA.

Cummins, J. D., \& Weiss, M. A. (2013). Analyzing firm performance in the insurance industry using frontier efficiency and productivity methods. InHandbook of insurance (pp. 795-861). Springer New York.

Diboky, F., \& Ubl, E. (2007, September). Ownership and efficiency in the German life insurance market: A DEA bootstrap approach. In 34th Seminar of the European Group of Risk and Insurance Economists (EGRIE), June.

Hardwick, P., Adams, M. B., \& Hong, Z. (2003). Corporate governance and cost efficiency in the United Kingdom life insurance industry. European Business Management School, University of Wales, Swansea.

Md Saad, N., Idris, H., \& Edzalina, N. (2011). Efficiency of life insurance companies in Malaysia and Brunei: a comparative analysis. International Journal of Humanities and Social Science, 1(3), 111122.

Kasman, S., \& Turgutlu, E. (2007, January). A comparison of chance-constrained DEA and stochastic frontier analysis: An application to the Turkish life insurance industry. In 8 Congreso Turco de Econometría y Estadística, Malasia.

Klumpes, P. J. (2004). Performance benchmarking in financial services: Evidence from the UK life insurance industry. The Journal of Business, 77(2), 257-273.

Retzlaff-Roberts, D., \& Puelz, R. (1996). Classification in automobile insurance using a DEA and discriminant analysis hybrid. Journal of Productivity Analysis,7(4), 417-427. 
Saad, N. M., Majid, M. S. A., Yusof, R. M., Duasa, J., \& Rahman, A. R. A. (2006). Measuring efficiency of insurance and Takaful companies in Malaysia using data envelopment analysis (DEA). Review of Islamic Economics, 10(2), 5.

Shujie, Y. A. O., Zhongwei, H., \& Genfu, F. E. N. G. (2007). On technical efficiency of China's insurance industry after WTO accession. China Economic Review, 18(1), 66-86.

Sinha, D., Pratap, R., \& Chatterjee, B. (2009). Are Indian life insurance companies cost efficient?. Biswajit, Are Indian Life Insurance Companies Cost Efficient.

Wei, H. (2009). Efficiency of insurance fund utilization in China's insurance companies: A resourcebased two-stage DEA model. Economic Research Journal, 8, 37-49. 